\title{
Applications of Aeromagnetic and Electrical Resistivity Data for Mapping Spatial Distribution of Groundwater Potentials of Dutse, Jigawa State, Nigeria
}

\author{
Chifu E. Ndikilar ${ }^{1}$, B. Y. Idi ${ }^{1}$, B.S. Terhemba ${ }^{1}$, I. I. Idowu ${ }^{1} \&$ S.S. Abdullahi ${ }^{1}$ \\ ${ }^{1}$ Department of Physics, Federal University Dutse, Jigawa State \\ Correspondence: Physics Department, Federal University Dutse, P.M.B 7156, Dutse, Jigawa State, Nigeria. Tel: \\ 234-8069-553-173. E-mail: ebenechifu@yahoo.com, belyus2000@gmail.com
}

Received: Nov. 22, 2018

Accepted: Dec. 4, 2018

Online Published: January 3, 2019

doi:10.5539/mas.v13n2p11

URL: https://doi.org/10.5539/mas.v13n2p11

The research is financed by Tertiary Education Trust Fund (TET Fund), Nigeria.

\begin{abstract}
Optimal mapping of groundwater resource is usually accomplished using integrated geophysical survey in which two or more techniques are applied. In this work, spectral analysis of aeromagnetic data was used to map the topography of the magnetic crystalline fresh basement underlying the water bearing aquifer of Dutse, Jigawa State Nigeria. Vertical electric sounding technique was used to detect the spatial distribution of the depths to the top of the aquifer within the same area. The overall goal of the work is to determine the groundwater potential of the area by mapping the spatial distribution of groundwater availability based on aquifer thickness and basement topography. The aquifer depth was found to be within the range of 5 to $15 \mathrm{~m}$ with a mean value of $10 \mathrm{~m}$. The basement was found to be highly undulating having depths ranging from 6 to $69 \mathrm{~m}$ with a mean value of $24 \mathrm{~m}$. The existence of isolated deep depressions within the basement which appears to be filled by water bearing sediments was thought to be favorable structures for groundwater accumulation. The spatial distribution of groundwater potential was therefore mapped in a reclassified image of three zones, high, moderate and low. The study therefore provides a vital tool for groundwater exploitation and management strategies.
\end{abstract}

Keywords: Groundwater, Spectral Analysis, Vertical Electric Sounding, Crystalline Basement, Aquifer, Dutse

\section{Introduction}

Topographic features of the crystalline basement are vital parameters that control the hydrogeologic characteristics of a given formation. The basement topography together with its associated structures such as dikes, faults and fractures control the accumulation and movement of ground water. In the basement complex, ground water normally occurs in the porous and permeable substrate which is an underground layer of water-bearing permeable rock of unconsolidated materials such as gravel, sand, confined by impermeable confining bedrock such as shale. It is however more prominent within the weathered and fractured basement where it could either be confined by overlying impermeable and high resistive rocks, or remains unconfined but trapped by the low permeable and highly resistive fresh basement. Aquiferous zones are usually found to have a wide range of undulating spatial geometry which affect the ground water potentiality of a given formation (Steinich et al., 1999). Thus in most cases basement relief determine the thickness of the aquifer.

Magnetic method of geophysical prospecting is very vital in investigating subsurface geology and identifying anomaly resulting from the magnetic properties of the underlying rocks. It is found to be very successful in delineating various subsurface formations due to relatively high susceptibility contrast between basement rock and sedimentary unit (Emujakporue et al., 2017). Several works were carried out for the purpose of delineating basement structural pattern and topology using aeromagnetic data (Osinowo et al., 2013; Steinich et al., 1999; Srivastava, 2002; Emujakporue et al., 2017 etc). Information about subsurface geometry, depth, thickness and lateral extent of the impermeable crystalline basement is very crucial for accurate hydrogeological characterization of a given formation. Magnetic method integrated with electrical resistivity can harmoniously be used to locate the permeable layer, fractures and estimate their thicknesses thereby providing possible relationship between aquifers and related features (Batista-Rodr'1guez et al, 2017). 
Several techniques of mapping basement as a source of magnetic anomaly is being practiced by many authors. These are grouped into graphic and computer modeling techniques (Gunn, 1997). Graphic techniques are based on the fact that deeper magnetic sources are associated with broader anomaly while shallower sources are associated with narrower anomaly. Thus the techniques can be accomplished by approximating the magnetic source with simple geometry. Depth estimation is achieved using model curve atlas produced by many authors (Parker 1963; Essa \& El-Hussain, 2017; Rambabu \& Sinha, 1986). Manual matching of the anomaly type curve is however time consuming and restricted to the curve type whose model is available (Gunn, 1997).

With the advent of computer and its routine capabilities of modeling by trial and error, several computer modeling algorithms were developed based on the computation of the effect of various geometries or sum of sources of geometries on the shape of the anomaly (Won \& Bevis, 1987). The modeling has significant advantage in that its routineness reduces the tediousness and cumbersomeness of graphic techniques. The most popular modeling and inversion techniques are Euler deconvolution developed by Reid et al., 1990; analytic signal (Nabighian,1984; Roest et al.,1992), spectral analysis (Spector \& Grant,1970) all of which produce geologic model with anomaly effect which match the observed magnetic anomaly. The Euler deconvolution however requires the choice of structural index which is challenging where the survey area contains a range of sources with significantly different geometries (Gunn, 1997). The computation of analytical signal on the other hand leads to the amplification of the of noise on a real data (Qin, 1994).

Spectral analysis however has the advantage of estimating the depth of anomaly source approximated by a prismatic block based on the logarithmic radial energy spectrum of the total magnetic intensity. The spectrum consists of a straight line whose gradient is related to the average depth to the tops of the prisms. Thus by dividing the study area into rectangular tiles, the mean depth to the top of the source at each point will be estimated with resolution relative to the number of the tiles. The method has the advantage of giving an estimate of the numerical value of the depth at each point (Chiozzi et al., 2005).

In this work, high resolution aeromagnetic and electrical resistivity data were used to respectively estimate the topography of fractured and crystalline basement of Dutse. The objective of the work is to determine the groundwater potential of the area by mapping the spatial distribution of groundwater availability within the study area. The work is based on the assumption of the fact that groundwater in crystalline basement mainly occur in fractured and weathered zone of the basement (Musa et al., 2013). Hence, the crystalline fresh basement beneath fractured basement serves as underground water repository trapped by fresh impermeable crystalline and denser materials such as granite, basalt or shale.

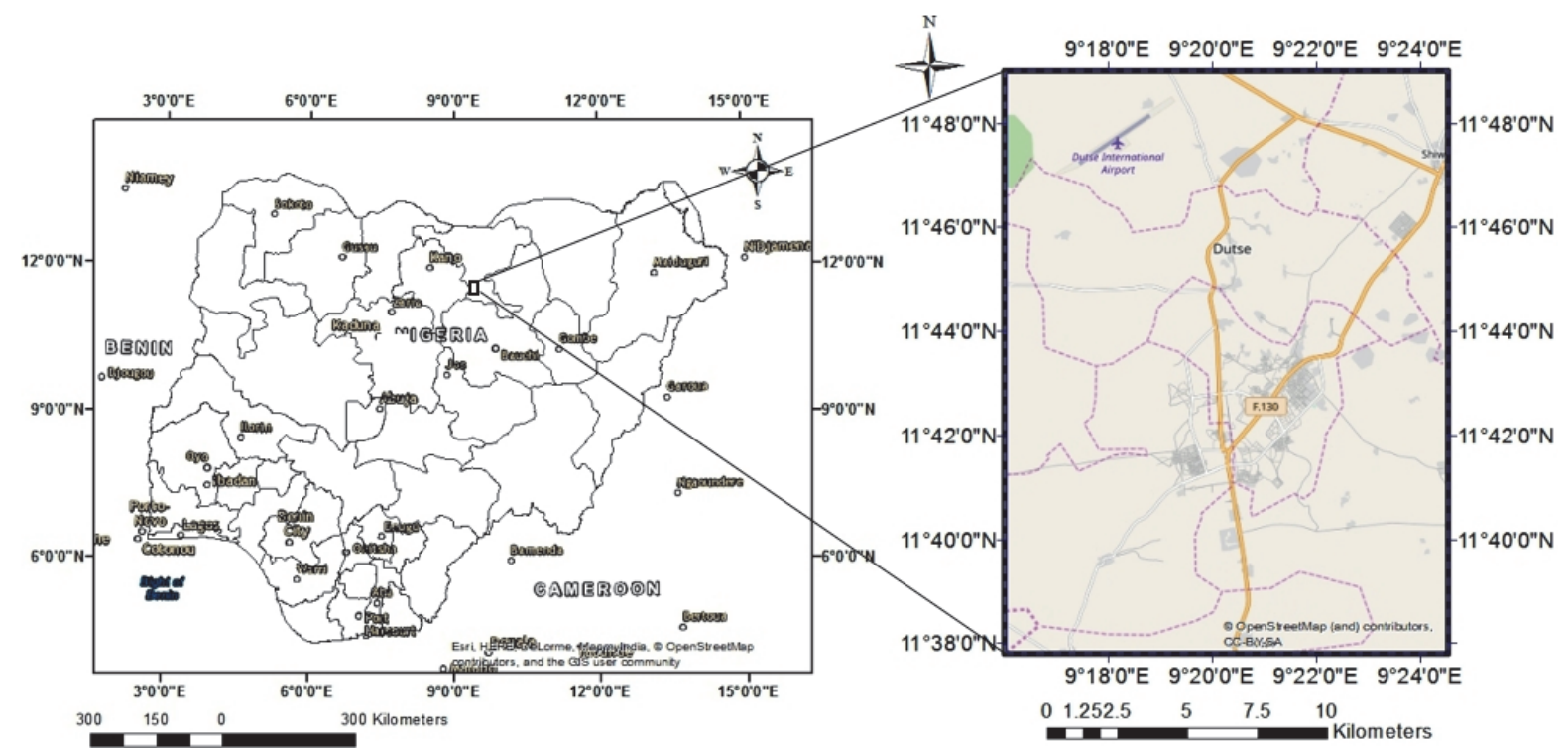

Figure 1. Map of Nigeria showing Jigawa State, the study area (in rectangle), geologic features and VES points

\section{Study Area}

The study covers a $720 \mathrm{~km}^{2}$ rectangular area enclosing Dutse, Jigawa State Nigeria and its surroundings (Fig. 1). It is geographically bound by lower left corner coordinates latitude $11^{\circ} 38^{\prime} 0.27^{\prime}$, longitude $9^{\circ} 15^{\prime} 56.34^{\prime \prime}$ and upper right corner coordinates latitude $11^{\circ} 48^{\prime} 4.43^{\prime \prime}$ longitude $9^{\circ} 24^{\prime} 0.23^{\prime \prime}$ at an average elevation of about $434 \mathrm{~m}$ above 
mean sea level. The area is geologically within the Precambrian basement complex of north central Nigeria (Obaje, 2009) and is therefore characterized by diverse landforms with few elevated landscape features of igneous rocks surrounded by relatively flat landscape. The rock type in the area is predominantly coarse porphyritic biotite granite and granitoid pan African older granitoide. Other members of the group available to a lesser extent are porphyritic younger granitoid of jurassics age and medium to coarse grained hornblende biotite granite also of pan African older granitoid (NGSA, 2017).

The study area is very close to the geologic contact boundary between the Precambrian basement complex and the Chad basin. Hence a quartenary clay deposit of the Chad formation occupied small portion of the area. According to Obaje (2009), the basement complex of north central Nigeria is subjected to high degree of weathering which led to the formation of thick weathered basement in some places. Studies on borehole logs within the area revealed that the aquiferous zones mainly occur within this weathered and fractured zones (Dewandel et al., 2017; Ismail \& Yola, 2012).

\section{Method}

\subsection{Theoretical Background}

The application of spectral analysis of potential field data for determination of the depth and extent of magnetic anomaly source is based on the analysis of the radially averaged power spectra of the data developed by Spector \& Grant (1970). The method was used by many authors (Negi et al., 1983; Blakely,1988; Chiozzi, et al., 2005) to determine the depth and extent of various magnetic sources of different shapes (Okubo et al., 1985; Stampolidis et al., 2005; Hsieh et al., 2014). The procedure involves 2-D Fourier Transform (FT) of the magnetic data and computation of the radially averaged power spectra of the transformed data. The power spectrum can be used to statistically estimate the depth to the top and bottom of the magnetic source.

The 2-D Fourier Transform FFT of a potential field data $f(x, y)$ is given by

$$
F\left(k_{x}, k_{y}\right)=\iint_{-\infty}^{\infty} f(x, y) e^{-i\left(k_{x} x+k_{y} y\right)} d x d y
$$

where $k_{x}$ and $k_{y}$ are the wave numbers in $x$ and $y$ directions respectively measured in radian per unit of $x$ and $y$. The FT of a potential field due to a prismatic body has a broad spectrum with a peak at a location determined by the dimension and depth of the prism (Geosoft, 2007). The spectrum $F\left(k_{x}, k_{y}\right)$ due to a prism is given by

$$
F\left(k_{x}, k_{y}\right)=e^{-h_{t} r}-e^{-h_{b} r}
$$

where $h_{t}$ and $h_{b}$ are respectively the depths to the top and bottom of the prism and

$$
r=\sqrt{k_{x}^{2}+k_{y}{ }^{2}}
$$

The peak wave number $\omega^{\prime}$ is given by

$$
\omega^{\prime}=\frac{\operatorname{In}\left(h_{b} / h_{t}\right.}{h_{b}-h_{t}}
$$

The radially averaged power density spectra $\Phi_{\Delta T}(k)$ is defined (Blakely, 1995) as

$$
\Phi_{\Delta T}(k)=\Phi_{M}\left(k_{x}, k_{y}\right) \times F\left(k_{x}, k_{y}\right)
$$

where $\Phi_{M}\left(k_{x}, k_{y}\right)$ is the power density spectra of the magnetization. For a randomly oriented magnetization, $\Phi_{M}\left(k_{x}, k_{y}\right)$ is a constant and thus the radially averaged power spectra was expressed by Tanaka et al. (1999) as

$$
\Phi_{\Delta T}(k)=A e^{2 k Z_{t}}\left[1-e^{-k\left(Z_{b}-Z_{t}\right.}\right]^{2}
$$

where $A$ is a constant, and $Z_{b}$ and $Z_{t}$ are respectively the depths to the bottom and top of the source. For a short wavelength (wavelength less than twice the thickness of the source, (6) can be written as

$$
\ln \left[\Phi_{\Delta T}(k)\right]^{1 / 2}=\ln B-k Z_{t}
$$

Thus the depth to the top of the source $Z_{t}$ can be estimated as the slope of the straight line fitting the low wave number (large wavelength) component of the spectrum. A typical radially averaged spectrum for magnetic data is made up of three components: a deep sourced component which is related to low wave number, a shallow sourced component related to larger wave number and a noise component.

At higher wave number on the other hand, (6) is approximated as (Hsieh et al., 2014) 


$$
\ln \left[\Phi_{\Delta T}(k)\right]^{1 / 2} / k=\ln D-k Z_{o}
$$

where $Z_{0}$ is the depth to the centroid of the source. Thus $Z_{0}$ can equally be obtained as the slope of a straight line fit to the spectra at low wave number component.

\subsection{Data Acquisition and Processing}

A high resolution airborne geophysical survey involving radiometric and magnetic surveys was carried out by the Nigerian Geological Survey Agency in collaboration with Fugro Airborne Survey Ltd, Johannesburg from 2004 to 2009 covering the entire country. The project mapped and developed an inventory of the country's mineral resources. Table 1 gives details of the survey equipment and flight parameters (Refordand James, 2010).

Table 1. Survey equipment and flight parameters

\begin{tabular}{ll}
\hline Data sensors on board & Airborne magnetic total field. and Multichannel radiometric gamma-ray spectrometer \\
\hline Flight line spacing & $500 \mathrm{~m}$ \\
Terrain clearance & $80 \mathrm{~m}$ \\
Flight direction & NW -SE \\
Tie line spectingf & $2000 \mathrm{~m}$ \\
Tie line direction & NE -SW \\
\hline
\end{tabular}

The acquired data was prepared in a Nigeria's standard map layout grid of 1:250,000 nationwide map sheets. The study area is covered by sheet number 145 with a coverage dimension of 5.5 by $5.5 \mathrm{~km}$. The data is corrected for the variation of field with latitude using International Geomagnetic Reference Field (IGRF). The reduction to pole correction was also applied so that observed anomalies are related only to the subsurface magnetic materials. Fig. 2 is the plot of the total magnetic anomaly map (in nT) of the study area. Both positive and negative anomalies of the total field are clearly discernible in the map.

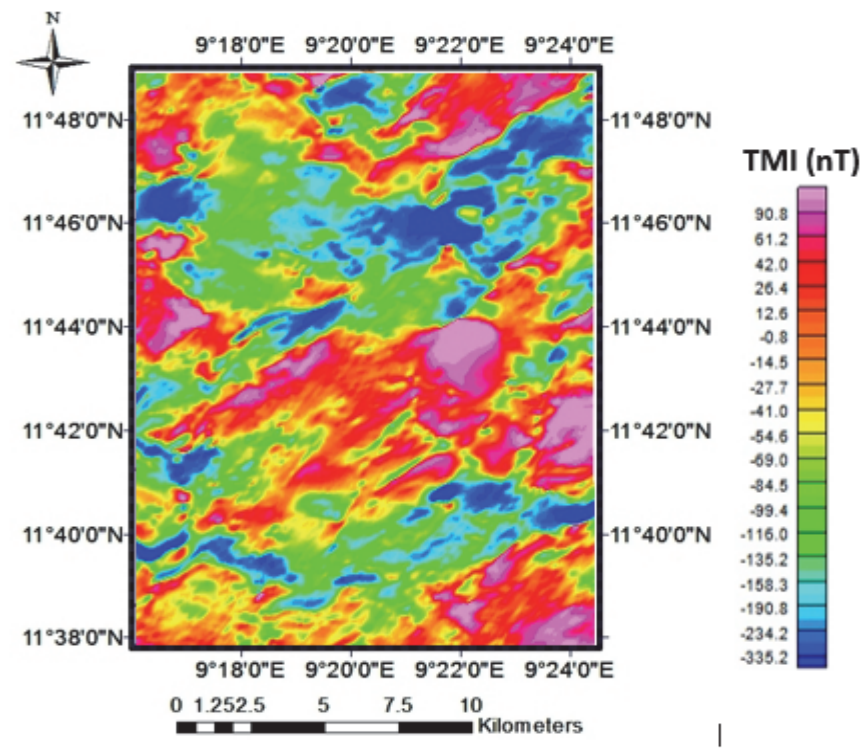

Figure 2. Contour map of the preprocessed total magnetic intensity resized to the study area.

The spectral analysis is accomplished by dividing the study area into 120 (10 by 12) square subdivisions of $6 \mathrm{~km}^{3}$ each, with overlap shift increment of $0.2 \mathrm{~km}$ in all directions. 2-D FFT was implemented on each of the 120 data blocks. Upward continuation filter was applied for each of the blocks in order eliminate anomaly due to shallower sources and emphasize on deeper sources. The radially averaged power spectra for each of the block was computed and displayed from where the parameters $Z_{t}$, was obtained accordingly. Fig.3 depicts how the parameters were obtained from the plots of the radially averaged power spectra for some selected square blocks. 

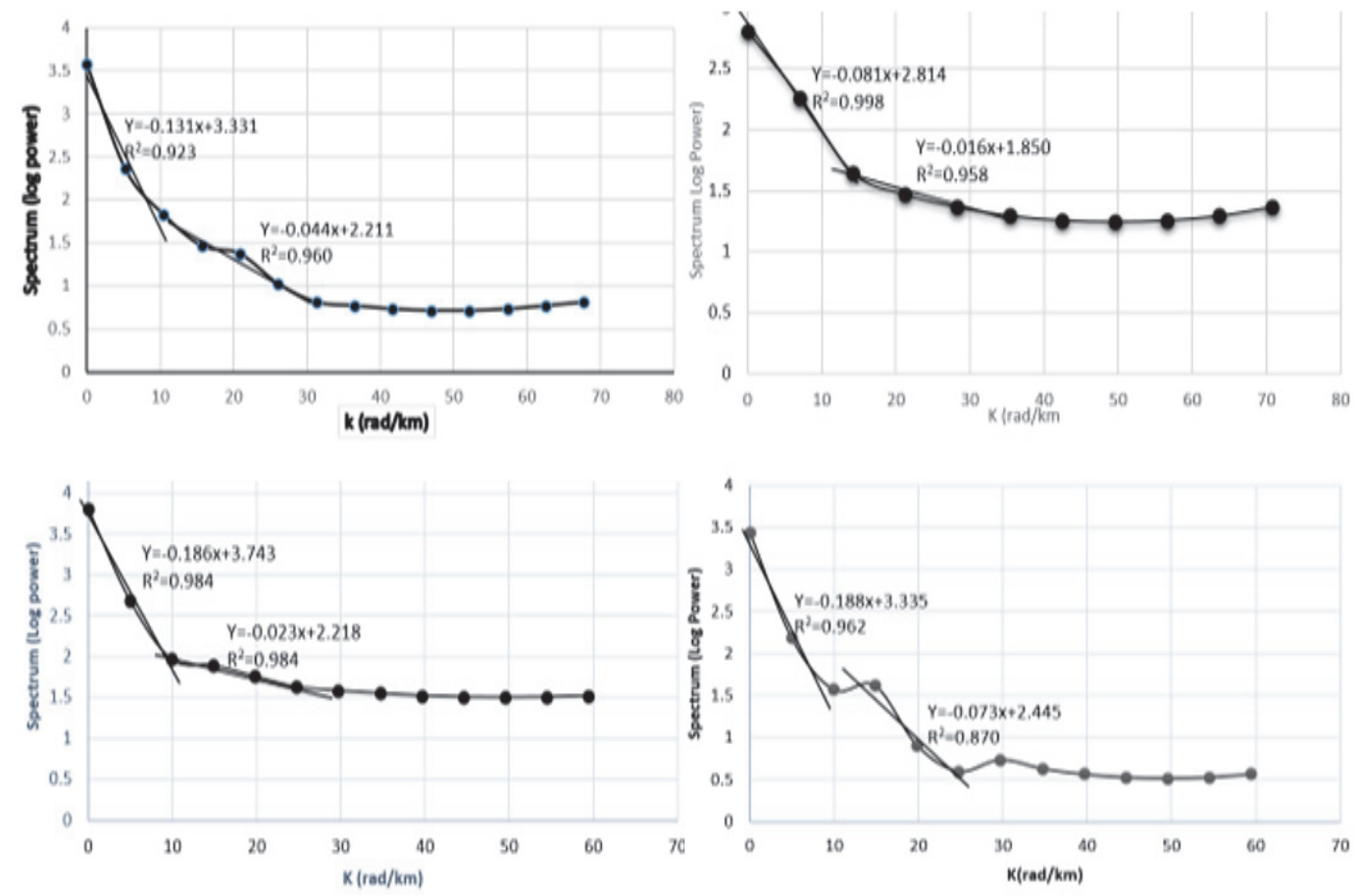

Figure 3. Typical radially averaged power spectrum.

The slopes of $y_{1}$ and $y_{2}$ give the values of $Z_{0}$ and $Z_{t}$ respectively.

Geoelectrical resistivity method was used to acquire resistivity and layer depth at various sounding stations within the study area. Twenty five VES sounding stations were identified across the area based on accessibility and proximity to existing groundwater sources. Schlumerger electrode configuration was used due to its high lateral resolution, with a maximum half current electrode separation $\mathrm{AB} / 2$ of $80 \mathrm{~m}$. The data were acquired with $\mathrm{ABEM}$ SAS 1000 terrameter.
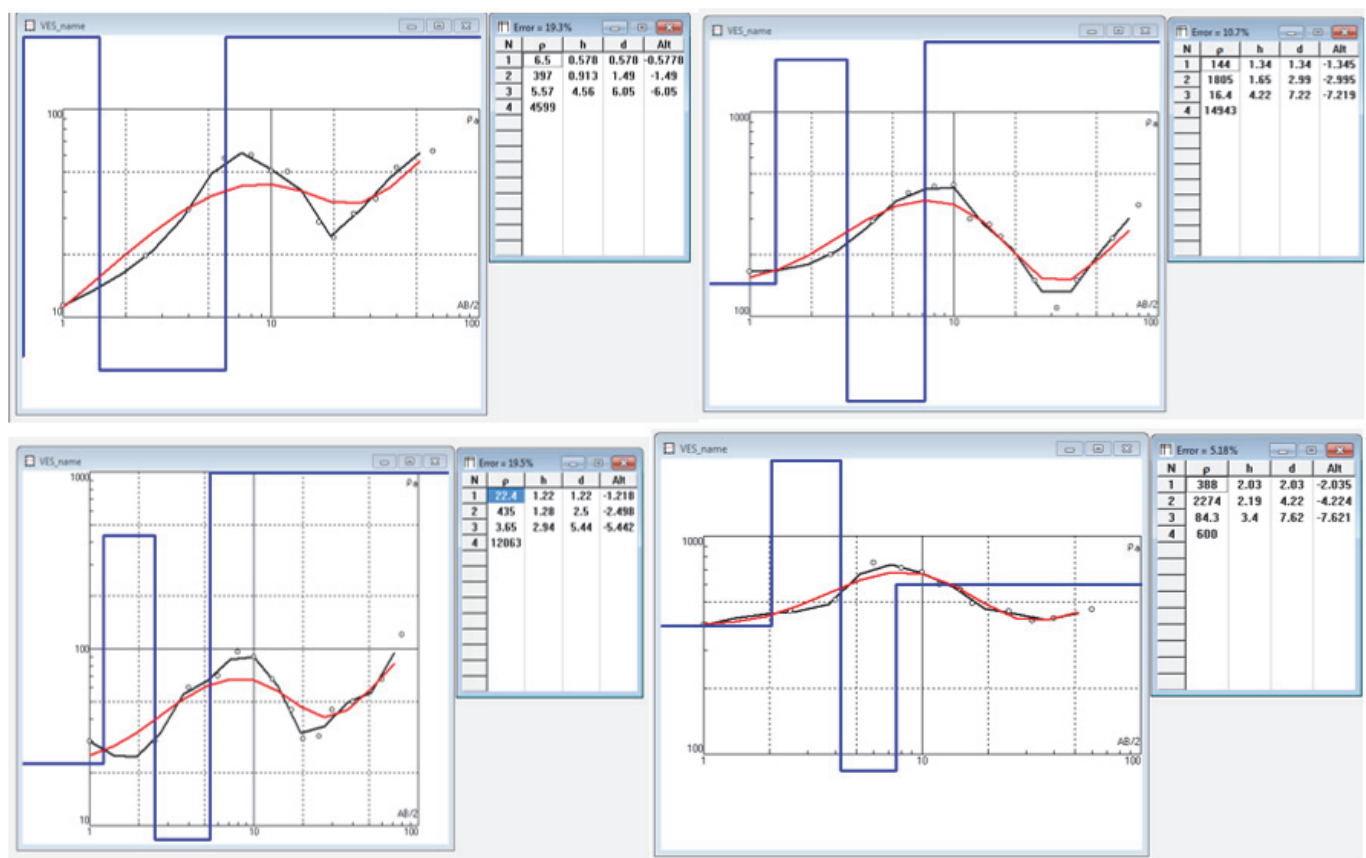

Figure 3. 1-D inversion model curve for some selected VES stations. 
All Schlumberger sounding curves were processed and modeled using Res2inv resistivity sounding interpretation software. Forward modeling and automated inversion processes were used interchangeably to produce best fit curves. Based on the aquifer characteristics of the formation as observed by Yelwa et al. (2015), the weathered and fractured basements were identified as the aquifers and their respective depth, thickness and resistivities were recorded accordingly. Field and model curves were carefully matched until optimal fittings were obtained with fitting error ranges from a minimum of $2.77 \%$ to a maximum of $19.6 \%$. Fig. 3 is a 1-D inversion model curve for VES 1.

\section{Results and Discussion}

Qualitative and quantitative interpretation of the magnetic data were done in order to establish the mean depth of the magnetic crystalline basement at the center of each rectangular grid. This enables the delineation of the boundary between the crystalline basement and the water-bearing fractured basement. The topography of the magnetic crystalline basement was found to be highly undulating ranging from $6 \mathrm{~m}$ to $69 \mathrm{~m}$ below the surface with a mean value of $24 \mathrm{~m}$.

On the other hand, the resistivity curves obtained are predominantly of KH type which indicate four geoelectric layers with $\rho_{1}<\rho_{2}>\rho_{3}<\rho_{4}$. (Fig. 3). The only exceptions are VES 11 and VES 19 where five geoelectric layers were detected. Comparison of the detected geoelectric layers with borehole logs obtained from drilling firm with respect to the study area shows that the top layer with mean resistivity of $208 \Omega \mathrm{m}$ consists of clay/laterite and sand. The second layer with a mean resistivity of $1431 \Omega \mathrm{m}$ is interpreted as the unsaturated permeable sand and gravels sediments. The third layer with relatively lower mean resistivity value of $181 \Omega \mathrm{m}$ is interpreted as the water bearing zone, made up of fractured and weathered basement. It overlays the highly resistive fresh basement which has a mean resistivity value of $11194 \Omega \mathrm{m}$. In VES 11 and VES 19 points where four layers were detected however, the forth layers were interpreted as the water bearing zones. This is based on the fact that unconfined aquifers generally consist of upper resistive unsaturated zones overlaying low resistive saturated zones (Olayinka, 1992; Olorunfemi and Fasuyi, 1993). Depth to the top of the aquifer ranges from $5 \mathrm{~m}$ to $15 \mathrm{~m}$ from the surface, with a mean value of $10 \mathrm{~m}$.

Pictographic view of the aquifer and basement topography of the study area is depicted in the 3-D surface plots of the depth to tops of the aquifer and the fresh basement shown in Fig. 4 (a and b). The figure indicates that the basement topography generally steeps toward the western portion of the study area and slopes toward the northwest. It can also be observed from the figure that the aquiferous zone is characterized by relatively gentle relief that ranges between $5 \mathrm{~m}$ to $15 \mathrm{~m}$ with a mean value of $10 \mathrm{~m}$ below sea level. The steeping up of the weathered layer toward the north roughly corresponds to the slopping down of the fresh basement in the north and northwestern portion of the map. Comparison with the geologic map of Nigeria (NGSA, 2017) shows that this northern border of the study area corresponds to the contact or transition zone between the continental crystalline basement and the Chad sedimentary formation.

The structural characteristics and topography of the basement indicates that the undulating nature of central portion of the study area gives space for progressive downslope accumulation of thick water bearing layer. Deep basement depression is observed around the northern corner of the map and at the center with northwest - southeast orientation. On the other hand, elevations of the basement were observed at the extreme southern portion and at the northeast corner of the area. While the basement depressions are associated with a relatively thicker waterbearing fills, the elevation especially the isolated one in the southern part of the area which has shallowest depth of $6 \mathrm{~m}$, is considered as intrusive into the sediment. The impermeable basement and its associated igneous bodies such as shale, intrusive, served as seal caps for the aquifers and thus increase the aquifer thickness within the region. It is widely believed that remarkable areas of groundwater availability correspond to the commonly occurring depression in crystalline bedrock due to intensive deposition of coarse gravel as a product of the bedrock's erosion (Srivastava, 2002). Thus in the absence of any buried channel of lesser permeability than the surrounding bedrock, the region serves as water trap and thus effective groundwater reservoir. 


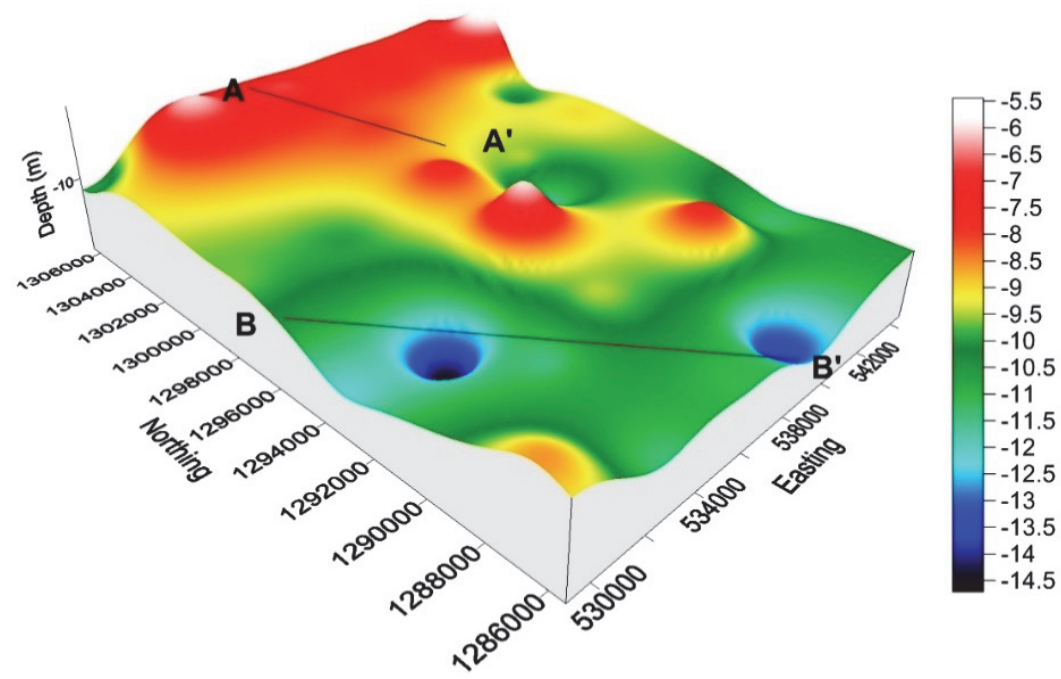

(a)

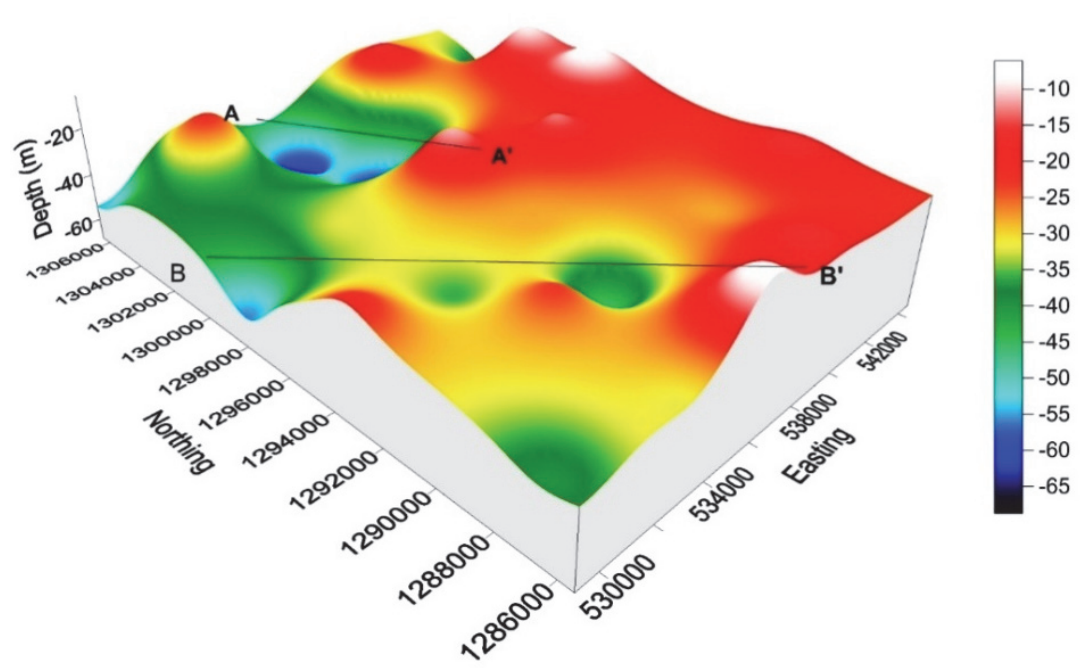

(b)

Figure 4. 3-D topographic maps (a) non-magnetic aquifer and (b) magnetic basement.

For qualitative interpretation of stratigraphic and hydrogeologic sequence of the formation, a cross sectional profiles A-A' and B-B' for cross sections of the two regions of deep depressions were plotted (Fig. 5). All the cross sectional plots indicate that the water bearing zones of the area occur as unconfined aquifer under water table condition underlaying the unsaturated lateritic sands. Since there is no evidence of the presence of any confining layer, the aquifer is assumed to be unconfined.

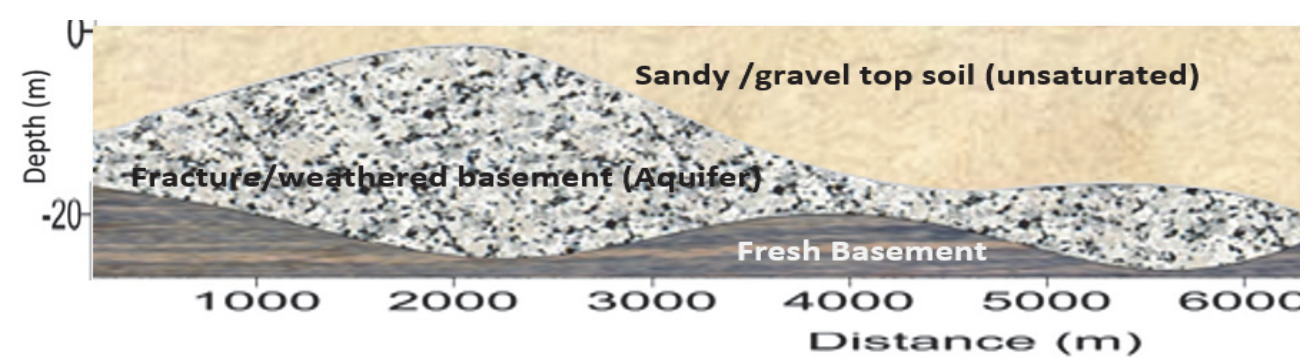

(a) Profile A-A' 


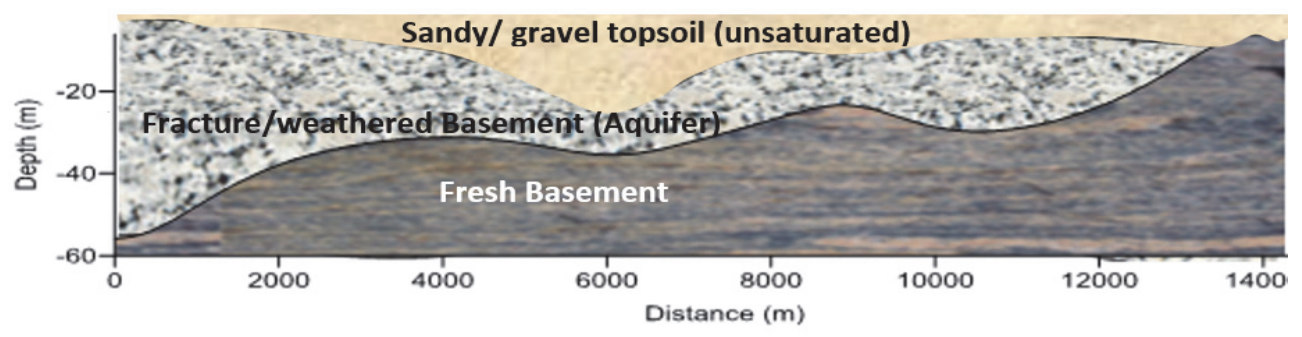

(b) Profile B-B'

Figure 5. Cross sectional profiles

In profile A-A', two regions of basement depressions are clearly visible at about $2300 \mathrm{~m}$ and $5500 \mathrm{~m}$ lengths of the profile. Both depressions coincide with deposition of the water-bearing zones fills with higher water bearing fill above the $2200 \mathrm{~m}$ depression. A closer look at profile B-B' also shows two depressions at $6000 \mathrm{~m}$ and $11000 \mathrm{~m}$ length of the profile. The water bearing fills above these points are to a lesser extent relative to profile A-A'. the basement intrusion observed in Fig. 4(b) is clearly discernible at the extreme end of the profile.

The four regions of deep basement depressions are considered as areas of major potential for large scale groundwater exploitation. However, the use of fertilizer, pesticides and herbicides for agricultural practice as well as livestock manures within the area create vulnerability for anthropogenic pollution in these reservoirs (Batista-Rodriguez et al., 2015).

Since knowledge of the aquifer geometry is vital for the assessment of ground potential of the area, a realistic distribution of its thickness above the crystalline basement is interpreted as the distribution of water bearing zones and thus the groundwater vulnerability of the area (Brunner et al., 2007). The spatial variation of the distribution of the aquifer is therefore considered as the spatial distribution of groundwater potential of the area. Consequently, the map of the spatial distribution of groundwater potential of the area was generated. The map was reclassified into three categories of water prospects as high, moderate and low (Fig. 6). The map will serve as a vital tool for groundwater management strategies and assessment of the potential impact of the region's groundwater plan over a reasonable period of time. This work therefore provides useful information about the suitability of aquifer for borehole construction and a means of consistent and economic provision of portable water supply to the dwelling communities.

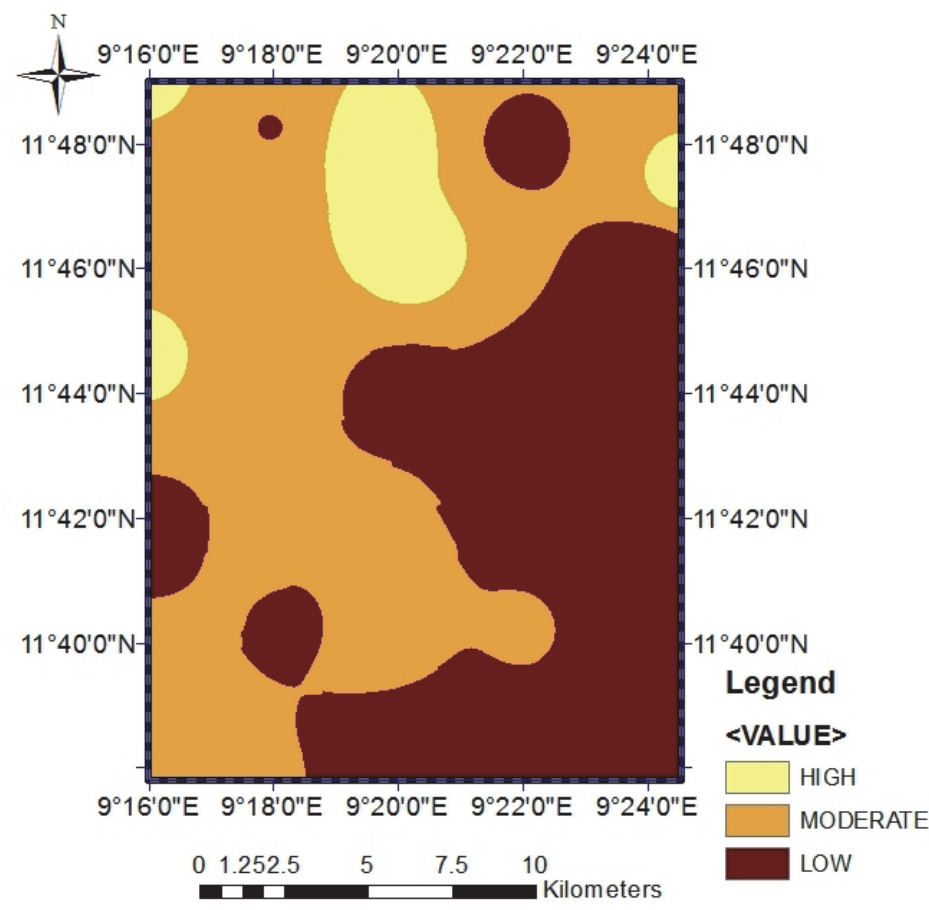

Figure 6. Map of spatial distribution of groundwater potential of the study area 


\section{Conclusion}

In this work, the topography of the crystalline basement underlying the water bearing fractured and weathered zone was mapped based on spectral analysis of aeromagnetic data of the study area. Topography of the top of the aquifer as well as the aquifer thickness were also mapped using geoelectrical method. The results were harmoniously used to map the spatial distribution of groundwater resources of the study area based on aquifer thickness and the basement geometry. It is shown that the occurrence of some isolated deep depressions of the basement and corresponding water bearing fills form a favorable mechanism for groundwater accumulation. It is however observed that such formation could equally be vulnerable to anthropogenic pollution due to persistence agricultural activities within the area. It is therefore recommended that for domestic exploitation of the resources within the area, assessment of groundwater quality should be carryout.

\section{Acknowledgments}

We acknowledge that this research project was sponsored by the Tertiary Education Trust Fund (TET Fund), Nigeria through the Institution Based Research (IBR) intervention, Federal University Dutse, 2017.

\section{References}

Batista-Rodr'iguez, Jos'e A., Caballero, A., P'erez-Flores, M., Carmenates, A., \& Almaguer, Y. (2017). 3D Inversion of Aeromagnetic Data on Las Tablas District, Panama. Journal of Applied Geophysics. https://doi.org/10.1016/j.jappgeo.2017.01.018

Blakely, R. J. (1988). Curie temperature isotherm analysis and tectonic implications of aeromagnetic data from Nevada. Journal of Geophysical Research, 93, 817-832. https://doi.org/10.1029/JB093iB10p11817

Blakely, R. J. (1995). Potential Theory in Gravity and Magnetic Applications. Cambridge University Press, Cambridge.

Brunner P., Hendricks H. J. Kgotlhang, L., Bauer-Gottwein P., \& Kinzelbach, W. (2007). How can remote sensing contribute in groundwater modeling? Hydrogeology Journal, 15, 5-18. https://doi.org/10.1007/s10040-006$0127-\mathrm{z}$

Chiozzi, P., Matsushima, J., Okubo, Y., Pasquale, V., \& Verdoya, M. (2005). Curie-point depth from spectral analysis of magnetic data in central-southern Europe. Phys. Earth Planet. Inter, 152, 267-276. https://doi.org/10.1016/j.pepi.2005.04.005

Dewandel, B., Jeanpert, J., Ladouche, B., Join, J., \& Maréchal, J. (2017). Inferring the heterogeneity, transmissivity and hydraulic conductivity of crystalline aquifers from a detailed water-table map. Journal of Hydrology, 550, 118-129. https://doi.org/10.1016/j.jhydrol.2017.03.075

Emujakporue, G., Ofoha, C., \& Kiani, I. (2017). Investigation into the basement morphology and tectonic lineament using aeromagnetic anomalies of Parts of Sokoto Basin, North Western, Nigeria. Egyptian Journal of Petroleum. https://doi.org/10.1016/j.ejpe.2017.10.003

Essa1, K., \& El-Hussein, M. (2017). 2D dipping dike magnetic data interpretation using a robust particle swarm optimization. Geoscientific Instrumentation Methods and Data System Discussions. https://doi.org/10.5194/gi-2017-39. 1-20

Geosoft. (2007). MontajMagmap filtering. 2-D frequency domain processing of potential field data extension for Oasis Montaj 6.4. Geosoft Inc. Canada.

Gunn, P. J. (1997). Quantitative methods for interpreting aeromagnetic data: a subjective review. AGSO Journal of Australian Geology \& Geophysics, 17(2), 105-113.

Hsieh, H., Chen, C., Lin, P., \& Yen, H. (2014). Curie point depth from spectral analysis of magnetic data in Taiwan. Journal of Asian Earth Sciences, 90, 26-33. https://doi.org/10.1016/j.jseaes.2014.04.007

Ismail, A. Y., \& Yola, A. L. (2012). Geoelectrical Investigation of Groundwater Potential of DawakinTofa Local Government Area of Kano State Nigeria. American International Journal of Contemporary Research, 2(9), 188-197.

Musa, O. K., Ogbodo, D. A., Jatto, S. S., \& Kudamnya, E. A. (2013). Evaluation of Groundwater Potential of Crystalline Basement Area of Kogi State Polytechnic, Osara Campus, North-Central Nigeria using Electrical Resistivity Method. Journal of Environment and Earth Science, 3(9), 171-183.

Nabighian, M. N. (1984). Towards a three-dimensional interpretation of potential field data via generalised Hilbert transforms: fundamental relations. Geophysics, 49, 780-786. https://doi.org/10.1190/1.1441706 
Negi, J., Agrawal, P., \& Rao, K. (1983). Three-dimensional model of the Koyna area of Maharashtra State (India) based on the spectral analysis of aeromagnetic data. Geophysics, 48(7), 964-974. https://doi.org/10.1190/1.1441522

NGSA. (2017). Geology and Mineral resources map of Jigawa State Nigeria [map], 1:500,000. Nigeria Geological Survey Agency (NGSA). Federal republic of Nigeria.

Obaje, N. G. (2009). Geology and Mineral Resources of Nigeria Lecture Notes in Earth Sciences. Springer, Springer-Verlag Berlin Heidelberg.

Olayinka, A. I. (1992). Geophysical siting of boreholes in crystalline basement areas of Africa. Journal of African Earth Sciences, 4(2), 197-207. https://doi.org/10.1016/0899-5362(92)90097-V

Olorunfemi, M. O., \& Fasuyi, S. A. (1993). Aquifer types and the geoelectric/hydrogeologic characteristics of part of the central basement terrain of Nigeria (Niger State). Journal of African Earth Sciences, 16(3), 309-317. https://doi.org/10.1016/0899-5362(93)90051-Q

Osinowo O, Akanji, A., \& Olayinka A. (2013). Application of high resolution aeromagnetic data for basement topography mapping of Siluko and environs, southwestern Nigeria. Journal of African Earth Sciences. https://doi.org/10.1016/j.jafrearsci.2013.11.005.

Parker Gay, S. (1963). Standard curves for interpreting magnetic anomalies over long tabular bodies. Geophysics, 28, 161-200. https://doi.org/10.1190/1.1439164

Qin, S. (1994). An analytic signal approach to the interpretation of total field magnetic anomalies. Geophysical Prospecting, 42, 665-675 https://doi.org/10.1111/j.1365-2478.1994.tb00234.x

Rambabu, H. V., \& Sinha, G. D. J. (1986). Magnetic anomalies over thin plates and their analysis. Earth Planet. Science, 95(3), 331-341.

Reford, S. W., \& James D. (2010). Nigeria's Nationwide High-resolution Airborne Geophysical Surveys. SEG Denver 2010 Annual Meeting, 1835-1839.

Reid, A. B., Allsop, I. M., Granser, R., Millet, A. L., \& Somerton, I. W. (1990). Magnetic interpretations in three dimensions using Euler deconvolution. Geophysics, 55, 80-91. https://doi.org/10.1190/1.1442774

Roest, W. R., Verhoef, V., \& Pilkington, M. (1992). Magnetic interpretation using the 3-D analytic signal. Geophysics, 57, 116-125. https://doi.org/10.1190/1.1443174

Spector, A., \& Grant, F. S. (1970). Statistical models for interpreting aeromagnetic data. Geophysics, 35, 293-302. https://doi.org/10.1190/1.1440092

Srivastava, A. (2002). Aquifer geometry, basement-topography and ground water quality around Ken Graben, India. Journal of Spatial Hydrology, 2(2), 1-18.

Stampolidis, A., Kane, I., Tsokas, G. N., \& Tsourlos, P. (2005). Curie point depths of Albania inferred from ground total field magnetic data. Surv. Geophys, 26, 461-480.

Steinich1 B., Bocanegra, G., \& Sánchez, E. (1999). Basement topography and fresh-water resources of the coastal aquifer at Acapetahua, Chiapas, Mexico. GeofisicaInternacional, 38(2), 107-115.

Tanaka, A., Okubo, Y., \& Matsubayashi, O. (1999). Curie point depth based on spectrumanalysis of the magnetic anomaly data in East and Southeast Asia. Tectonophysics, 306, 461-470. https://doi.org/10.1016/S0040

Won, I. J., \& BeviS, M. G. (1987). Computing the gravitational and magnetic anomalies due to a polygon: Algorithms and Fortran subroutines. Geophysics, 52, 232- 238. https://doi.org/10.1190/1.1442298

Yelwa, N. A., Hamidu, H. L., Falalu, B. H., Kana, M. A., \& Madabo, I. M. (2015). Groundwater prospecting and Aquifer Delineation using Vertical Electrical Sounding (VES) method in the Basement complex terrain of Kumbotso Local Government Area of Kano State Nigeria IOSR. Journal of Applied Geology and Geophysics, $3(1), 1-6$.

\section{Copyrights}

Copyright for this article is retained by the author(s), with first publication rights granted to the journal.

This is an open-access article distributed under the terms and conditions of the Creative Commons Attribution license (http://creativecommons.org/licenses/by/4.0/). 